\title{
THE LIMITS OF INTERACTION AND CELEBRATIONS WITH NON-MUSLIMS IN A PLURALISTIC SOCIETY-(AN ANALYTICAL STUDY)
}

\author{
Muhammad Usman Khalid \\ Ph.D Scholar, \\ Department of Islamic Studies, \\ University of Engineering \& Technology, \\ Lahore, Punjab, Pakistan, \\ ORCID: https://orcid.org/0000-0001-6391- \\ 8474.
}

\author{
Dr. Iftikhar Aalam \\ Assistant Professor, \\ Islamic studies Dept. University of Okara, \\ Okara, Punjab, \\ Pakistan
}

Dr. Abdul Razaq

Chairman,

Islamic Studies Dept. Ghazi University,

Dera Ghazi Khan,

Punjab, Pakistan

ORCID: https://orcid.org/0000-0002-2152-4060 .

Article DOI: https://doi.org/10.36713/epra5967

\begin{abstract}
In this article, it has been endeavoured to analyze the concepts of The limits of interaction and celebrations with nonMuslims in a pluralistic society. Actually, the pluralistic Religious pluralism is a combination of two words. "Religion and pluralism" follows them separately. Religion (noun) is the meaning of the way, attitude, origin and belief. The literal meaning of religion is the method or the way. The literal meaning of religion is "the road", which goes on. It is derived from the Arabic word "z-ah-b", Which means to go (walk) or pass away. After all, religion is the code of conduct by which human beings can succeed in the world and the hereafter. This way is called religion. Moreover, Greetings to non-Muslims in a pluralistic society, Exchange of gifts in a pluralistic society, Marrying a non-Muslim in a pluralistic society, Participation in non-Muslim celebrations of plural society, The slaughter of non-Muslims in a pluralistic society and its limits for Muslims, Condolences to non-Muslims in a pluralistic society and participation in funerals, Attending non-Muslim funerals in a pluralistic society, Participation in national celebrations and festivals in a pluralistic society, The problem of treatment and medicine from non-Muslims in a pluralistic society are the main issues discussed here in detail.
\end{abstract}

KEY WORDS: Pluralistic, Society, Muslims, celebrations, History, philosphy, peace

INTRODUCTION AND DATA Description Islam recognizes the differences between religions and recognizes a society in which people of different religions live. The Qur'an is wise:

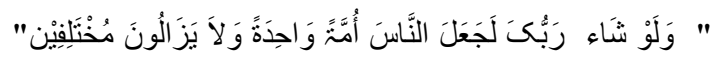

$$
\begin{aligned}
& \text { "Surely your Lord could have made all }
\end{aligned}
$$

[1] Surah Hood : 118 
mankind one group, if He please, but they will follow a different course."

In this verse, it is clearly stated that the religion of truth is one and the same in the sight of Allah Almighty and His pleasure is that people should accept it, but His will is not that all human beings should have the religion of truth. It has given them freedom of choice. They can choose whichever path they want and follow whatever religion they want. It is inevitable that there will be mutual relations between the people who live in the society. The teaching of Islam is that these relations should be based on justice and good conduct and differences of religions should not be allowed to stand in the way. Allaah says :

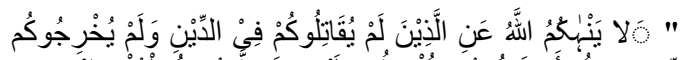
مِّن

"Allah does not forbid you to deal kindly and justly with those who have not fought you in religion and have not driven you out of your homes. God loves those who do justice."

This verse is very important in relation to social relations with non-Muslims. It mentions nonMuslims who are not ready to fight Muslims, but live together in peace and tranquility. There are two words to read:

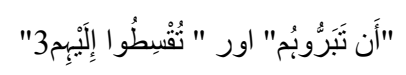

"Bur" means good behavior and merciful reward. It has the connotation of being as good as possible. The installment has been taken by some commentators in the sense of justice, ie deal with non-Muslims with justice. And that means they have to be moderate in their dealings with nonMuslims. Don't be too close to them, don't stay too far away from them.

Ibnul Arbi Maliki Says:[4]

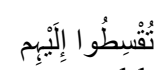

It means giving them some of your wealth as a merciful reward" .

These teachings of the Qur'an have been observed by Muslims in every age. During the Makkahn period, they lived with and among the polytheists.

[2] Surah Al-Mumtahinah ;8

[3] Al-Asfihani, Raghib, Imam, Al-Mufrdat fi Ghareeb ul Quran, (Egypt: Darul Saadah, 1322AH), p, 93

[4] Abul Hassan Al-Mawardi, Al-Nikat Waluyoon ( Tafseer Almawardi),( Maktbah Al-Waqfia, 2011) p, 223/4
There were Jewish tribes around Madina and they were accompanied by Muslims. There were good social relations between the followers of these different religions. Allah's Messenger (peace and blessings of Allah be upon him) never exaggerated them and never tried to limit them. Celebrations - An important part of social life is in the nature of man to meet other human beings on different occasions, to share in their joys and to share in their joys, to comfort them when they are in trouble and $\mathrm{He}$ should seek consolation and sympathy from others when he himself has an affliction. On occasions of joy, happiness and sorrow, when people from different relationships gather, they are called celebrations. These celebrations can be social as well as religious. Religious ceremonies also include certain rituals, which are based on a belief. When people from different walks of life in a multi-religious society hold their ceremonies, they also invite followers of other religions because of their social ties. While Muslims invite their non-Muslim neighbors, visitors, business associates and sometimes religious figures to their celebrations, non-Muslims also invite their Muslim friends to their celebrations. The question arises as to what are the limits and restrictions on the participation of Muslims in non-Muslim ceremonies, which should be observed? In the present era, this question has also become important because of the tendency of Muslims to invite non-Muslims to their ceremonies and non-Muslims to invite Muslims to their ceremonies in order to promote sectarian harmony. Has grown and is being called a need of the hour. Monotheism One of the basic tenets of Islam Before looking at the answer to the above question and considering its details, it seems necessary to shed some light on the importance of monotheism in Islam. Monotheism is one of the basic tenets of Islam. In contrast, he has sharply criticized polytheism. At the time of the revelation of the Qur'an, people were involved in polytheism and idolatry. Christians exaggerated and made Jesus God. Some of its sects believed in the 'Aqanim-e-Salatha'. The Quraysh had made thousands of gods and goddesses, before whom they bowed their heads. The Qur'an clarifies the error of all these sects and makes shirk an unforgivable crime:

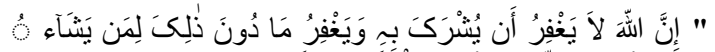

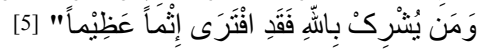

Surah Al-Nisa 4:48 
"Allah does not forgive shirk alone, but $\mathrm{He}$ forgives as many sins as $\mathrm{He}$ wills for whomever $\mathrm{He}$ wills. Whoever associates anything with Allah, then he has forged a lie and committed a grievous sin. "It is narrated on the authority of Aisha that the Messenger of Allah (saw) said: If he is present, there will be three types of deeds in his book of deeds. Some deeds will be those which Allah will not forgive under any circumstances and these will be polytheistic deeds. Allaah says (interpretation of the meaning):"

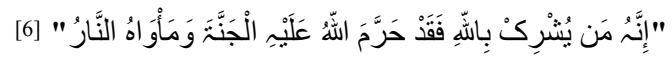

"Whoever associates anything with Allah, Allah has forbidden Paradise to him, and his abode is Hell."

Therefore, when attending the ceremonies of nonMuslims, one must abstain from all acts that are explicitly polytheistic, or which contain evidence of polytheism. There is another principle that must be kept in mind in this regard. That is, Islamic law urges Muslims to maintain their identities and forbids them to imitate other nations. It is narrated on the authority of Hazrat Abdullah bin Umar that the Prophet (peace and blessings of Allaah be upon him) said:

$$
\text { "من تشبّر بقوم فهو منهم " [7] }
$$

"Anyone who imitates a nation is one of them." In another hadith, he said:

$$
\text { "ليس منا من نشبّّ بغيرنا " [8] }
$$

"He is not one of us who imitates others." In the time of the Prophet, Jews and Christians were counted among the religious nations. In worship and in society, he performed many things that became his identity. Allah's Messenger (peace and blessings of Allah be upon him) forbade Muslims to imitate him in these deeds.

\section{Greetings to non-Muslims in a pluralistic society:}

When attending an event, the first encounter is with the host. If he is a non-Muslim, can he be greeted? There are different rules in the hadiths

\section{[6] Surah Al-Maidah 5:72}

[7] Sunan Abu Dawood, Kitabul Libas, Bab fi Lubsulshahrah, Hadith no, 4031

[8] Sunan Al-Termazi, Kitabul Istizan, Hadith no, 2695 regarding greeting non-Muslims. In some ahaadeeth it is forbidden to greet them, while it is proven from some of the Sahaabah and their followers that they used to greet them. Can There is also a debate over what words to use to greet or respond to greetings. Can they be greeted in the same way as Muslims? Or will other appropriate words be used for them?

Syed Jalaluddin Umri has written in detail on this subject. (Refer to him for the hadiths and relics of the Companions).

"We should think of a society that is a mixed and mixed society of Muslims and non-Muslims, that is, a pluralistic society, where there are different cultural, social, economic, purposeful relations between the two and both legal and constitutional relations. I'm tied up. In such a society, if nonMuslims are greeted in a polite manner, it will not be an anti-Salaf act. In this way, they may gradually become accustomed to Islamic etiquette and their meaning may become clearer to them. If it feels abominable, other words of respect, love and kindness can be used for them. However, care must be taken not to use expressions that are specific to another religion or culture, and not to use words that contradict Islamic beliefs. "9

Exchange of gifts in a pluralistic society:

Gift exchange ceremonies, if happy, are also presented with gifts. Hadiths show that gifts can be given to non-Muslims and their gifts can be accepted. Kasra (King of Iran), Caesar (King of Rome) and other kings sent gifts in the service of the Prophet (sws), which he accepted and sometimes he also sent gifts in response to them. The king of the Hamir tribe, Zwizan, sent a precious pair to his service. He accepted it and sent him a similar precious pair as a gift. Najashi Shah of Abyssinia gave him a mule as a gift, which he used for riding. The King of Alexandria (Egypt) sent many gifts in your service, such as a thousand shekels of gold, twenty (20) soft clothes, a mule called Daldal, a donkey named Yafur, a glass cup, a wooden jar, a mirror., Comb, etc.

Marrying a non-Muslim in a pluralistic society: Muqawqas Shah of Egypt, as we mentioned earlier, had sent with him two slaves and a slave, one of whom he had taken to his homeland, Yemen. So this text justifies marriage with nonMuslim People of the Book. As for the problem of other Muslims, there is definitely a text in it. The guidance is from the Almighty.

[9] Ghair Mulmoun sy Taalukat aour Un k Haqooq, p, 67 


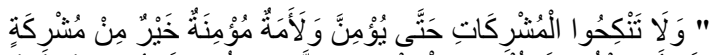

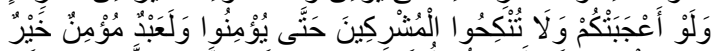

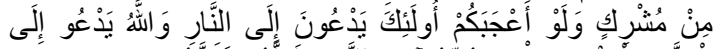

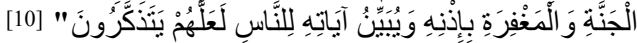 "And do not marry idolatrous women until they become MuslimsIndeed a Muslim slave- girl is better than a (free) idolatress, however pleasing she may seem to youNor give (the Muslim women) in marriage to idolaters till they embrace IslamAnd certainly a Muslim slave is better than an idolater, even though he should please youThese (idolaters and disbelievers) call you to Hell while Allah invites, by His Decree, to Paradise and Forgiveness and explains His Verses clearly to people so that they may take direction and guidance"}

The commentary in Dure Mansoor states that it is not permissible to marry a polytheist:

Imam Hakim (he called it Sahih) narrated from Mu'adh Jahni (may Allah be pleased with him) that the Messenger of Allah (may Allah bless him and grant him peace) said: Whoever gives to someone for the sake of Allah and not for the sake of Allah. He gave and loved someone for the sake of Allah and became angry with someone for the sake of Allah. He completed his faith.[11]

People of the Book, even if the woman is not a Muslim, the children born of such a marriage will be called Muslims, because the lineage is always with the man and if the man is a Muslim, then the children belonging to his lineage will also be Muslims.

The problem of marrying a Qadiani or an apostate in a pluralistic society:

Imam Abu al-Hasan Ali ibn Abi Bakr alMarghinani said:

"اعلم أن تصرفات المرتد على أقسام نفاذ بالاتفاق كالاستيلاء

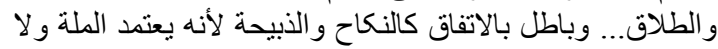

ملة له" .

"It should be noted that there are several types of apostate dispositions: One type is unanimously enforced, such as subjugation and divorce. The second type is unanimously invalid, such as nikah and zabiha, because they are both dependent on the nation and the apostate has no nation."

Ibn 'Abidin al-Shami says:

[10]

Surah Al-Baqarah, 2: 221

[11] Tafseer Aldurar Al-Mansoor, 543/1

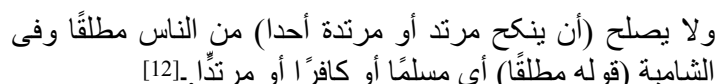

"And the marriage of an apostate or an apostate with a human being is absolutely not valid, that is, neither with a Muslim, nor with a disbeliever, nor with an apostate. "

In Fatwa Alamgiri, it is written that the marriage of an apostate is void:

فلا يجوز له أن يتزوج امر أة مسلمة و لا مرتدة ولا ذمية ولا حرة

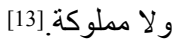

"Therefore, an apostate is not allowed to marry a Muslim woman, an apostate, a dhimmi woman, a free man or a female slave." From all the above quotations it is clear that a Muslim man cannot marry an apostate. Similarly, a Muslim woman can marry only a Muslim man.

\section{Participation in non-Muslim celebrations}

\section{of plural society:}

Eating and drinking is considered an essential part of all celebrations. If it doesn't happen at an event, it seems incomplete. In short ceremonies, tea biscuits, fruits, fruits, etc. are sufficient, while in large ceremonies, a variety of food is arranged. It is important to keep in mind the basic teachings of Islam regarding food and drink:

Alcohol and other alcoholic beverages are commonly used in non-Muslim celebrations. In Islam, it is explicitly forbidden and it is urged to avoid it. Allaah says (interpretation of the meaning):

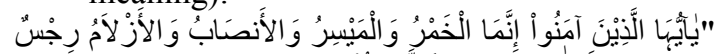

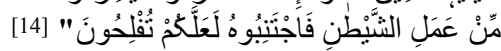

"O Believers! Wine and gambling and idols mounted (for worship) and divining arrows (for seeking luck, all) are filthy works of Satan. So turn away from them (completely) so that you may prosper."

The slaughter of non-Muslims in a pluralistic society and its limits for Muslims:

One of the animals that Islam forbids eating is pork. This has been clarified in several places in the Holy Qur'an. Allah Almighty has said:

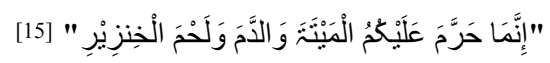

"If there is any restriction on you from Allah,

[12] Shami, Ftawa Shamia, p, 200/3

[13] Ftawah Aalamgiri, p, 580/3

[14] Surah Al-Maidah 5:90

[15] Surah Al-Baqarah 2: 173 
it is that you should not eat carrion, but should eat it with blood and pork."

In mahrams (as is clear in the above verse) there is also dead. In Surat al-Ma'ida (verse 3) it is stated that whether he died a natural death or was strangled or injured or fell from a high place or died by hitting the horns of another animal, it is haraam to eat its meat. Is.

It is also haraam to eat the meat of an animal that has been slaughtered in the name of other than Allah or on the thresholds of idols.

In this verse, the word) طَعَامُ food) is mentioned, which is commonly found, but it is narrated from various companions and followers that it means sacrifice. Allama Ibn Katheer in his commentary on this verse, after quoting the sayings of his companions and followers, wrote:

$$
\begin{aligned}
& \text { و هذا أمر مجمع عليم بين العلماء أن ذبائهم حلال للمسلمين، لأنهم }
\end{aligned}
$$

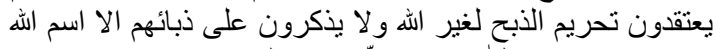

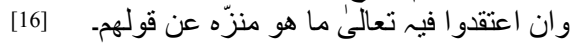

"The consensus of the scholars is that the slaughter of the People of the Book is permissible for Muslims, because they consider slaughter in the name of other than Allah to be haraam and slaughter in the name of Allah alone, even though they are about Allah Almighty. Some have beliefs that he is free from."

Sayyid Abu al-'Ali Maududi has pointed out an important point in the following verse: Have been done. From this it became clear that the People of the Book should abide by the rules of purity and purity which are necessary from the point of view of Shari'ah, or if their food contains haraam things. For example, if they slaughter an animal without mentioning the name of Allah or use the name of someone other than Allah on it, then it is not permissible for us to eat it. Similarly, if there is alcohol or pork or any other haraam thing on their table, we cannot associate with them.[17] Items made by non-Muslims, such as sweets or other food items, pizza, etc., are permissible for Muslims to use. Provided that no haraam thing is mixed in them and they are not offered to idols. As at McDonald's pizza, some people suspect that it contains pork

[16] Tafseerul Quran Al-Azeem, p, 321/2

[17] Moudodi , Abu Aala, Molina Syed, Tafheemul Quran, (New Delhi : Markazi Maktabah Islami Publishers), p, 446-448/1

\section{Condolences to non-Muslims in a pluralistic society and participation in funerals:}

If a non-Muslim loved one, neighbor, business partner or visitor dies, he should be offered condolences. This is a social requirement, which is permitted by Shariah. However, while offering condolences, one should not utter anything that contradicts any Islamic belief. A Christian used to attend the meeting of Hazrat Hassan Basri. When he died, they offered condolences to his brother. He said:

"Be patient with the trouble that has befallen you." Allah will give you a good reward for it. "[18]

\section{Attending non-Muslim funerals in a pluralistic society:}

Non-Muslims can attend the funeral. The purpose is to express the relationship with the deceased and to comfort and console his loved ones and relatives. In funerals, of course, religious matters and instructions are observed, non-Muslims will manage it in their own way, but a Muslim is allowed in any case to have a human relationship and express sympathy. So be present on this occasion and attend his funeral. Numerous Companions and great followers give practical proof of this

However, it is important to be careful that a Muslim does not engage in any act that is illegal from an Islamic point of view, such as setting fire to a pyre, that Islamic law does not allow the burning of human corpses, or prayers for forgiveness. And reciting the Qur'an for the sake of reward, that it is explicitly forbidden for a nonMuslim deceased to do so. In Quraan Majeed:

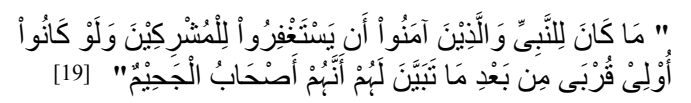

"It is not the glory of the Messenger (blessings and peace be upon him) and the dignity of the believers that they pray for forgiveness of the polytheists, even though they are kindred, after it has become clear to them that they (the polytheists) are the inmates of Hell."

In the same way, once the Messenger of Allah visited his mother's grave. There, a state of weeping fell upon him and the Companions, seeing him, began to weep. On this occasion he said:

[18] Kitabul Khiraj, p, 217

[19] Surah tauba 9:113 


$$
\text { استأذنت ربى أن استغفر لها فلم يأذن لى_20] }
$$

"I asked my Lord for permission to seek forgiveness for my mother, but I did not get permission".

Participation in national celebrations and

festivals in a pluralistic society:

In our country, some events are held which are of a national nature and do not usually involve participatory activities, although the organizers of the event are non-Muslims, so some of the events have their own culture. A glimpse of In India, for example, the country's flag is hoisted and saluted on Independence Day, Republic Day and some other occasions. When the national anthem is recited on these occasions, it is considered necessary for all present to stand. Can a Muslim participate in such events?[21]

In films made in Muslim countries, it is possible for Muslims to imitate other religions in fictitious roles, to imitate their rituals, to use tilak and to utter obscene words against Muslims. This should also be uprooted- .

At the beginning of some ceremonies, candles are lit, coconuts are boiled, ribbons are cut, or other such things are done. All of these activities are in conflict with Islamic culture, so their performance is not desirable, but if they do not have a polytheistic background, there may be scope to participate in such events. Participation in religious ceremonies Some ceremonies of nonMuslims are of a purely religious nature. Participatory functions are performed in them. It is not normal for Muslims to attend such events under normal circumstances.

Allaah says (interpretation of the meaning :

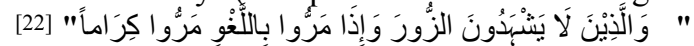

" (And the servants of the Most Gracious are those) who do not bear witness to falsehood, and when they pass by a nonsense, they pass by like noble men."

In this verse, 'Zor' means some of the Companions and followers (such as Hazrat Abdullah bin Abbas, Abu Al-Aliyah, Mujahid, Taus, Ibn Sirin, Rabi 'bin Anas and Zahak etc.) have taken the festivals of the polytheists.[23]

In the time of the Prophet, a man made a vow that he would slaughter a camel at a place called

[20] Mahnama Al-Rashad, shumara no 335, vol 40, november 2000

[21] ibid

[22] Surah Al-Furqan, :72

[23] Tafseer ibne Kathir, Aljamei Mae Liahkam ul Quran, p, 356/5
Bawana. He mentioned his vow to the Messenger of Allah (peace and blessings of Allah be upon him) and asked: Is there any idol of the Jahiliyyah that is worshiped? People said: No. He asked: Are any of the festivals of Jahiliyyah celebrated there? The people replied: No. Then he said: Fulfill your vow. A woman came to the service of Allah's Messenger (peace and blessings of Allah be upon him) and said: I had made a vow that I would sacrifice animals in some place (where people used to slaughter animals in the pre-Islamic era). He asked: Did the people of Jahiliyyah offer sacrifices to an idol of clay or stone there? He replied: No. Then he said: Fulfill your vow.24 It is clear from these ahaadeeth that when it is forbidden to slaughter the vows in places where idols are worshiped and polytheistic acts are performed, it will not be permissible to participate in the festivals held there. Allama Ibn Taymiyyah, after quoting the above hadiths, has written: "When a devout person is forbidden to attend ignorant festivals and places of worship, then participation in ignorant festivals itself will be prohibited in the first place."25 For this reason, many of the Companions of Ifta 'have declared the participation of non-Muslims in religious ceremonies to be forbidden. However, if a person has to attend a non-Muslim religious ceremony for the purpose of religious expediency, national requirements, da'wah spirit, compilation of heart or Islam, he may be allowed to do so, provided he participates in a religious act. Don't be and stay away from the religious rituals that are performed on this occasion. It is known from the books of Sira that the Messenger of Allah (peace be upon him) used to attend the festivals of Okaz, Zulmajna and Zulmajaz and used to meet the people there and present the message of Islam to them. Similarly, if there is a party on the occasion of various festivals as a goodwill gesture, such as Holi Milan, etc., and religious ceremonies are not performed in it, then in view of the wider da'wah interests, goodwill and communal harmony Can be attended. An example of a religious ritual is the wearing of a qashqa on the forehead, which is related to Hindu religious rites, so it is not permissible. 26

[24] Sunan Abu Dawood, Hadith no, 3313

[25] Kifaytul Mifti, Ftawa Rashidiyah,( Deuoban: Rashidiyah Kutub Khana), p, 556/9

[26] Khalid Saifullah Rehmani, Molina, Muslimanon aur Ghair Muslimon k drmiyan Rwabit Islami Taleemat ki roshni min, ( New Delhi:2013 ) p, 27 
In some ceremonies in India, the song 'Vande Mataram' is sung. The song is openly polytheistic, as it addresses 'Bharat Mata'. According to the Hindus, 'India' has been portrayed as a goddess and idols have been erected and temples have been built in different parts of the country. Based on this, it is not permissible for a Muslim to sing this song. The resolution was passed in this regard on June 20-22, 2004 at the seminar of Islamic Jurisprudence Academy, New Delhi, Hyderabad:

"Songs like Vande Mataram have polytheistic words and the idea of giving the land of India the status of a deity is found. Therefore, it is haraam for Muslims to recite such a song and they must avoid it. 27

\section{The problem of treatment and medicine}

\section{from non-Muslims in a pluralistic society:}

There are a few texts that show that there is a justification for this.

Imam Ahmad, Ibn Majah and Abu Dawud have narrated from Jabir that they say that when Abi ibn Ka'b fell ill, the Prophet sent a doctor to treat him and he put a scar on his arm vein. It is narrated on the authority of Ibn 'Umar (may Allaah be pleased with him) in Musnad Ahmad that he said:' Umar (may Allaah be pleased with him) sent a physician to me to examine my wound. He said: He drank grapes from Allah and likened grapes to blood.[28]

Ibn al-Qayyim said: "Having hired Abdullah ibn Ariqat al-Dawli for guidance during the migration of the Prophet (peace and blessings of Allaah be upon him) proved that even though he was a kaafir, it is permissible to refer to a kaafir in medicine, medicine, writing, arithmetic, etc. There should be no work in which the court is a condition and just because you are a kaafir does not mean that you should not rely on anything at all, especially in times of migration, there can be no work that is more dangerous than showing the way. 29

\section{CONCLUSION}

As we know, meeting two or more people together creates a family, and a few families together form one society by living together in one place. In the same way, this process takes on

[27] Naii msail aur fiqh academy ky faisly, ( India: Islami Fiqh Academy, 2014), p, 5

[28] Ibne Majah , Muhammad bin Yazid, Sunan ibne Majah,(Maktabah Islamiyah, 2015) p, $315 / 2$

[29] Ibne Qayyam, Bdai Al-Fwaid,(Al-Jiddah, AlMajma Al-Fiqhul Islami, 2008) p, 208/2 the form of a global society, taking on a region, country and then global. The society is like the human body, just as a perfect and healthy body requires that all its organs are natural. Stay connected to each other. Likewise, for the formation of a strong society, it is essential that unity and harmony between different people be maintained.

In his book "In The Quest for Meaning: Developing a Philosophy of Pluralism", Tariq Ramadan spoke of promoting mutual respect and tolerance among people of different faiths and ideas in a pluralistic society. He says that the world is shrinking like a global village. Europe and America are no longer a distant world. Now Muslim scholars are realizing that they are living in a world where different religions, philosophies and ideologies are revived. The believers are living. In the texts of the Qur'an and Sunnah, the most important attribute of the society which has been declared as the desired society of God is that it imprints the worship of Allah on the obedience and worship of Allah, and people worship and worship the zakat with full religious spirit Play with. Individual and collective agreements should be enforced; the spirit of witnessing the truth is alive and the collective existence of Muslims is the title of martyrdom of truth in the world, regardless of personal or group interest and without taking into account the reproach of an offender; The needs of parents and honors should be respected; the rights of the orphans are protected; prostitution and indecency are a taboo thing and arrangement to block all avenues of promotion; Always be vigilant and avoid such forms of tyranny and other forms of repression on the life and death of such criminals. God-ordained sentences should be imposed without exception; a general atmosphere for inviting goodwill and preventing evil is established in society, and society at all levels is sensitive in this regard; $\mathrm{Be}$ judged on the basis of justice; no superiors can exploit or infringe on their rights; opportunities for people to develop their academic skills to the best of their ability and showcase their abilities in the field of their own tastes. Be available; the system of wealth distribution should be just and fair and remove the inequities arising out of it collectively. Always be dynamic for crying; God's law is fully organized at every level and no fear, interest, greed or pressure can be obstructed in its implementation; brotherhood, brotherhood, sympathy and Behaviors are common and people should not mock one another for personal or 
group displeasure, to preach to each other, or to engage in racial discrimination; full respect for religion and religious ideology. To be settled in mosques and to be included in the basic priorities of the teaching of religion and its broadcasting society; To exaggerate, the spirit of sacrifice for the sake of life and peace of the heart is imperative; minority groups have full freedom to protect their lives and practice their religion and they are completely devoid of political and cultural rights. I have discussed the above, which will be helpful in determining the boundaries and scope of a pluralistic society. 